\title{
PENGARUH KOMITMEN ORGANISASI, BUDAYA ORGANISASI, GAYA KEPEMIMPINAN DAN LINGKUNGAN TERHADAP KINERJA KARYAWAN PADA INDUSTRI KECIL
}

\author{
Siswanto Wijaya Putra \\ Email :wijayaputras@yahoo.co.id
}

\begin{abstract}
Abstrak :Penelitian ini menganalisis pengaruh variabel komitmen organisasi, budaya organisasi, kepemimpinan, dan lingkungan kerja fisik terhadap kinerja karyawan pada industri kecil tas dan kulit di Tanggulangin Sidoarjo. Kinerja karyawan merupakan issue yang menarik, karena akan mempengaruhi kinerja perusahaan secara keseluruhan. Populasi penelitian adalah karyawan yang ada di industri kerajinan kulit, tas dan sepatu. Tujuan penelitian ini adalah untuk mengetahui pengaruh komitmen organisasi, budaya organisasi, kepemimpinan, dan lingkungan kerja fisik terhadap kinerja.Teknik sampling yang digunakan proporsional random sampling.Teknik analisis data digunakan regresi linear berganda.Hasil penelitian menunjukkan bahwa komitmen organisasi, budaya organisasi, kepemimpinan, dan lingkungan kerja fisik berpengaruh terhadap kinerja.
\end{abstract}

Kata kunci: Komitmen organisasi, budaya organisasi, gaya kepemimpinan, lingkungan, kinerja karyawan

\section{PENDAHULUAN}

Karyawan atau sumber daya manusia (SDM) dalam perspektif manajemen modern merupakan asset yang penting bagi perusahaan.SDM merupakan aset vital pada hampir semua jenis organisasi yang menjadi pilar utama sekaligus penggerak roda organisasi dalam upaya mewujudkan visi dan misinya.Sehingga manajemen akan berusaha mengelola SDM secara profesional agar terwujud suatu keseimbangan antara kebutuhan karyawan dengan keinginan dan kemampuan organisasi perusahaan. Karyawan dengan kinerja yang tinggi akan meningkatkan kinerja perusahaan secara keseluruhan. Kinerja yang dicapai oleh perusahaan pada dasarnya adalah prestasi para anggota yang ada dalam organisasi atau perusahaan itu sendiri mulai dari tingkat eksekutif sampai pada pegawai operasional.

Manajemen selaku agent akan berusaha mengoptimalkan kinerja perusahaan. Kinerja perusahaan salah satunya akan dipengaruhi oleh kinerja sumber daya manusia. Untuk itu manajemen dituntut untuk dpat mengoptimalkan kinerja karyawan atau sumber daya manusia yang dimiliki.Permasalahan mengenai kinerja merupakan permasalahan yang akan selalu dihadapi oleh pihak manajemen perusahaan, karena itu manajemen perlu mengetahui faktor-faktor yang mempengaruhi kinerja karyawan.

Manajemen dalam upaya meningkatkan kinerja karyawan harus mampu merekayasa sumber daya yang dimiliki perusahaan sedemikian rupa sehingga tercipta sinergi yang solid dalam suatu perusahaan. Dalam suatu perusahaan

Siswanto Wijaya Putra, adalah Dosen Prodi Manajemen Keuangan STIE Kertanegara Malang 
tentunya banyak faktor yang mempengaruhi seseorang untuk mencapai tujuan yang telah ditetapkan, sedangkan jalannya perusahaan akan diwarnai oleh perilaku individu yang merasa berkepentingan dalam kelompoknya masing-masing. Perilaku individu yang berada dalam perusahaan akan mempengaruhi perusahaan baik secara langsung maupun tidak langsung, hal ini akibat adanya kemampuan individu yang berbeda-beda dalam menghadapi tugas atau aktivitasnya. Setiap manusia atau seseorang selalu mempertimbangkan perilakunya terhadap segala apa yang diinginkan agar dapat tercapai tanpa menimbulkan konflik baik secara individu maupun kelompok, sehingga kinerja dapat tercapai sesuai dengan yang diinginkan.

Perusahaan akan berusaha mencapai tujuannya dengan baik, untuk itu diperlukan komitmen pihak-pihak yang berada didalamnya. Komitmen karyawan merupakan bagian penting bagi yang berpengaruh pada kinerja kayawan. Dengan memberi perhatian yang penuh dan membuat karyawan percaya terhadap organisasi akan diperoleh komitmen karyawan. Jika komitmen karyawan telah diperoleh akan didapatkan karyawan yang setia, bekerja sebaik mungkin untuk kepentingan organisasi. Keadaan ini sangat baik bagi pencapaian tujuan organisasi, karena organisasi mendapat dukungan penuh dari anggotanya sehingga bisa berkonsentrasi secara penuh pada tujuan yang diprioritaskan.

Komitmen organisasi merupakan sikap yang mencerminkan sejauh mana seseorang individu mengenal dan terikat pada organisasinya Griffin (2004).Komitmen organisasi sebagai sebuah sikap yang merefleksikan loyalitas karyawan kepada organisasi dan merupakan suatu proses berkelanjutan dimana anggota organisasi mengungkapkan perhatian mereka terhadap organisasi, terhadap keberhasilan organisasi serta kemajuan yang berkelanjutan (Luthans: 2006). Pentingnya komitmen organisasi karena: (1) Pengaruhnya pada turnover, (2) Hubungannya dengan kinerja yang mengasumsikan bahwa individu yang memiliki komitmen cenderung mengembangkan upaya yang lebih besar pada pekerjaan (Morrison, 1997).

Jati dan Khusaini (2003) yang melakukan penelitian pada Karyawan Bank BRI cabang Pasuruan menemukan bahwa komitmen berpengruh terhadap prestasi kerja karyawan.Tobing dan Diana (2009) komitmen organisasi berpengaruh positif terhadap kinerja karyawan PT. Perkebunan Nusantara III di Sumatera Utara.

Perusahaan sebagai suatu organisasi tidak dapat dilepaskan dengan budaya organisasi.Budaya organisasi merupakan falsafah, ideologi, nilai-nilai, anggapan, keyakinan, harapan, sikap dan norma-norma yang dimiliki secara bersama serta mengikat dalam suatu komunitas tertentu.Budaya organisasi merupakan sikap dan perilaku individu dalam bekerjasama untuk mencapai tujuan organisasi juga didasarkan pada sistem nilai yang berlaku. Rachmadita dkk (2011) menyatakan bahwa budaya memberikan orientasi kepada manusia berkenaan dengan bagaimana melakukan tindakan pada situasi tertentu.

Budaya antar organisasi akan sangat mungkin berbeda. Bahkan organisasi yang sama seiring dengan perubahan waktu akan sangat mungkin budaya organisasinya juga berubah. Organisasi merupakan bukanlah sesuatu yang statis, namun sangat dinamis. Hal ini karena secara spesifik budaya dalam organisasi akan ditentukan oleh kondisi team work, leaders dan characteristic of organization serta administration process yang berlaku. Sehingga ketika faktor-faktor penentu budaya organisasi tersebut berubah atau berbeda maka budaya organisasi juga akan cenderung berbeda. 


\section{MODERNISASI, Volume 11, Nomor 1, Februari 2015}

Budaya organisasi mempunyai peran yang sangat penting dalam upaya pencapaian tujuan organisasi.Mengapa budaya organisasi penting, karena merupakan kebiasaan-kebiasaan yang terjadi dalam hirarki organisasi yang mewakili norma-norma perilaku yang diikuti oleh para anggota organisasi.Budaya juga memiliki fungsi penting bagi perusahaan.Budaya organisasi merupakan sistem penyebaran kepercayaan dan nilai-nilai yang berkembang dalam suatu organisasi dan mengarahkan perilaku anggotaanggotanya.Budaya organisasi dapat menjadi instrumen keunggulan kompetitif yang utama, yaitu bila budaya organisasi mendukung strategi organisasi, dan bila budaya organisasi dapat menjawab atau mengatasi tantangan lingkungan dengan cepat dan tepat.

Budaya organisasi akan mempengaruhi semua aspek organisasi dan perilaku anggota organisasi yang kemudian menentukan kinerja anggota dan organisasi (Wirawan, 2007). Temuan penelitian Soedjono (2005) menunjukkan budaya organisasi berpengaruh terhadap kinerja organisasi.

Dalam suatu organisasi peran kepemimpinan memegang peran yang penting. Hal ini karena kepemimpinan akan memberikan dorongan dan semangat bagi karyawan dalam melaksanakan tugas. Kepemimpinan (leadership) sebagai suatu proses dengan berbagai cara mempengaruhi orang atau sekelompok orang untuk mencapai tujuan bersama. Northouse, 2003) kepemimpinan adalah suatu proses dimana individu mempengaruhi kelompok untuk mencapai tujuan umum. Sedangkan menurut Martoyo (2007) kepemimpinan adalah keseluruhan aktifitas dalam rangka mempengaruhi orang-orang agar mau bekerja sama untuk mencapai suatu tujuan yang memang diinginkan bersama. Kepemimpinan berkaitan erat dengan pekerjaan yang harus diselesaikan (task function) dan kekompakan orangorang yang dipimpinnya (relationship function). Dalam lingkungan kerja peran pemimpin sangat penting dalam mempengaruhi moral dan kepuasan kerja yang kemudian berpengaruh pada kinerja orang yang dipimpinnya (Yuk1, 2005).

Kepemimpinan sebagai salah satu penentu arah dan tujuan perusahaan harus mampu mensikapi perkembangan zaman ini. Pemimpin yang tidak dapat mengantisipasi perubahan, atau setidaknya tidak memberikan respon, besar kemungkinan akan memasukkan organisasinya dalam situasi stagnasi dan akhirnya mengalami keruntuhan.

Kepemimpinan adalah masalah yang berhubungan dengan intelejensi, kepercayaan, kebaikan, keberanian, dan kedisiplinan (Agustian, 2006). Kepemimpinan yang hanya bergantung pada aspek intelejensi akan mengakibatkan munculnya pemberontakan. Praktek kepemimpinan yang bergantung pada kebaikan saja, akan menimbulkan kesan yang lemah. Sikap percaya yang

berlebihan juga mengakibatkan kebodohan. Terlalu mengandalkan kekuatan dari keberanian, akan mengakibatkan tindak kekerasan. Penerapan kedisiplinan dan pengaturan yang terlalu keras, akan mengakibatkan tindak kekejaman. Seseorang baru dapat menjadi pemimpin apabila dia sudah memiliki kelima aspek tersebut, dan sanggup menjalankannya dengan seimbang.

Widyatmini dan Hakim (2008) Kepemimpinan berpengaruh positif terhadap kinerja karyawan.Lingkungan dapat dibagi dalam dua dimensi yaitu lingkungan fisik dan sosial.Lingkungan kerja fisik merupakan segala sesuatu yang bersifat nyata yang berkenaan dengan kondisi tempat atau ruangan dan kelengkapan materi atau peralatan yang diperlukan karyawan untuk bekerja.Lingkungan fisik merupakan segenap faktor fisik yang bersama-sama merupakan suatu suasana fisik yang melingkupi suatu tempat kerja. Lingkungan kerja fisik merupakan kondisi tempat karyawan bekerja yang mencakup: teknik penerangan, suhu udara, suara 
kebisingan, penggunaan warna dan ruang gerak yang diperlukan (Mangkunegara, 2005:105).

Lingkungan kerja fisik dalam suatu perusahaan merupakan suatu kondisi pekerjaan untuk memberikan suasana dan situasi kerja karyawan yang nyaman dalam pencapaian tujuan yang diinginkan oleh suatu perusahaan.Kondisi kerja yang buruk berpotensi menjadi penyebab karyawan mudah jatuh sakit, mudah stress, sulit berkonsentrasi dan menurunnya produktivitas kerja. Jika ruangan kerja tidak nyaman, panas, sirkulasi udara kurang memadai, ruangan kerja terlalu padat, lingkungan kerja kurang bersih, berisik, akan berdampak pada kenyamanan kerja karyawan. Sedangkan lingkungan non fisik merupakan semua keadaan yang terjadi yang berkaitan dengan hubungan kerja, baik hubungan dengan atasan maupun hubungan dengan sesame rekan kerja, ataupun hubungan dengan bawahan. Temuan penelitian Mahardiani dan Pradhanawati (2013) menunjukkan lingkungan fisik berpengaruh terhadap kinerja karyawan pada karyawan Outsourcing.

Sumber daya manusia yang berupa karyawan bagi perusahaan merupakan asset, demikian juga dalam industri kecil dan menengah (UKM). Karyawan merupakan faktor yang memegang peran penting dalam pencapaian tujuan perusahaan. UKM tentunya akan selalu dihadapkan pada kemampuan manajerial pemilik atau pengusaha dalam memanage sumber daya yang dimiliki perusahaan. Kemampuan manajerial pengusaha UKM dengan industri besar tentunya akan sangat berbeda. UKM seringkali dihadapkan bukan saja pada keterbatasan permodalan, market, tetapi juga system produksi dan manajemen SDM. Penelitian ini dilakukan pada industri kecil dan menengah di sentra industry industry sepatu dan tas kulit Daerah Tanggulangin Sidoarjo.

Tujuan dari penelitian ini adalah sebagai berikut: 1) untuk menganalisis pengaruh komitmen organisasi terhadap kinerja karyawan, 2) untuk menganalisis pengaruh budaya organisasi terhadap terhadap kinerja karyawan, 3) untuk menganalisis pengaruh gaya kepemimpinan terhadap kinerja karyawan dan 4) untuk menganalisis pengaruh lingkungan terhadap kinerja karyawan.

\section{TINJAUAN PUSTAKA}

\section{Kinerja Karyawan}

Kesuksesan dan kinerja suatu perusahaan bisa dilihat dari kinerja yang telah dicapai oleh karyawannya, oleh sebab itu perusahaan menuntut agar para karyawannya mampu menampilkan unjuk kinerja yang optimal. Yuniningsih (2002) bahwa baik buruknya kinerja yang dicapai oleh karyawan akan berpengaruh pada kinerja dan keberhasilan perusahaan secara keseluruhan.

Kinerja karyawan merupakan tingkat keberhasilan karyawan dalam melaksanakan tugas dan tanggung jawabnya. Mathis dan Jackson (2002) menyatakan bahwa kinerja pada dasarnya adalah apa yang dikerjakan dan yang tidak dikerjakan oleh karyawan. Kinerja karyawan mempengaruhi seberapa banyak karyawan kontribusi kepada organisasi.Kinerja karyawan dipengaruhi oleh dua faktor, yaitu faktor eksternal dan internal.Faktor internal merupakan faktor yang berasal dari dalam diri karyawan, yang meliputi kepuasan kerja dan komitmen organisasional.Sedangkan faktor eksternal merupakan faktor yang berasal dari luar diri karyawan, yang meliputi kepemimpinan, keamanan dan keselamatan kerja, serta budaya organisasi. 
Umam (2010) pada dasarnya, penilaian kerja merupakan faktor kunci dalam mengembangkan suatu organisasi secara efektif dan efisien karena adanya kebijakan atau program yang lebih baik atas sumber daya manusia yang ada dalam organisasi.Penilaian kinerja individu sangat bermanfaat bagi dinamika pertumbuhan organisasi secara keseluruhan, melalui penilaian tersebut, kondisi kinerja karyawan dapat diketahui.

Bernadin (2007) menjelaskan bahwa kinerja seseorang dapat diukur berdasarkan 6 kriteria yang dihasilkan dari pekerjaan yang bersangkutan. Keenam kriteria tersebut adalah : 1) Kualitas, 2) Kuantitas, 3) Ketepatan waktu, 4) Efektifitas, 5) Kemandirian, 6) Komitmen. Banyak faktor yang mempengaruhi kinerja karyawan. Timpe (1993) ada tiga faktor penentu kinerja: 1) Tingkat keterampilan, dalam hal ini menyangkut: pengetahuan, kemampuan, kecakapan interpersonal serta kecakapan teknis (skill dan ability), 2) Tingkat upaya: karyawan yang hanya memiliki ketrampilan yang baik tidak akan dapat menyelesaikan pekerjaannya dengan baik apabila tidak mempunyai upaya sama sekali. Pada intinya, karyawan harus memiliki motivasi dalam bekerja, 3) Kondisi-kondisi eksternal: sejauh mana kondisi-kondisi eksternal mendukung produktivitas karyawan (lingkungan kerja karyawan).

\section{Komitmen Organisasi}

Komitmen dari seorang karyawan terhadap organisasinya dapat menjadi instrumen penting untuk meningkatkan kinerja dari karyawan tersebut (Khan et al., 2010).Komitmen organisasional merupakan suatu keadaaan di mana seorang karyawan memihak organisasi tertentu serta tujuan-tujuan dan keinginannya untuk mempertahankan keanggotaan dalam organisasi tersebut (Robbins dan Judge, 2008).Sedangkan menurut Griffin (2004), komitmen organisasi adalah sikap yang mencerminkan sejauh mana seseorang individu mengenal dan terikat pada organisasinya. Seseorang individu yang memiliki komitmen tinggi kemungkinan akan melihat dirinya sebagai anggota sejati organisasi. Komitmen merupakan sikap yang merefleksikan loyalitas karyawan pada organisasi dan proses berkelanjutan di mana anggota organisasi mengekspresikan perhatiannya terhadap organisasi dan keberhasilan serta kemajuan yang berkelanjutan.

Anggota organisasi yang berkomitmen terhadap organisasinya mungkin saja mengembangkan pola pandang yang lebih positif terhadap organisasi dan dengan senang hati tanpa paksaan mengeluarkan energi ekstra demi kepentingan organisasi (Anik dan Arifuddin, 2003).Hal tersebut menunjukkan bahwa komitmen organisasional memiliki arti yang lebih dari sekedar loyalitas yang pasif, tetapi melibatkan hubungan aktif dan keinginan karyawan untuk memberikan kontribusi yang berarti pada organisasinya.

Ada tiga dimensi komitment organisasi, yaitu: Pertama: affective commitment. Komitmen afektif menunjukkan kuatnya keinginan seseorang untuk terus bekerja bagi suatu organisasi karena ia memang setuju dengan organisasi itu dan memang berkeinginan melakukannya. Affective commitment mengacu pada keterikatan emosional, identifikasi serta keterlibatan seorang karyawan pada suatu organisasi.Komitmen afektif seseorang ini menjadi lebih kuat bila pengalamannya dalam suatu organisasi konsisten dengan harapan-harapan dan memuaskan kebutuhan dasarnya dan sebaliknya.Pegawai yang mempunyai komitmen afektif yang kuat tetap bekerja dengan perusahaan karena mereka menginginkan untuk bekerja di perusahaan itu.Kedua: Continuance commitmen ataukomitmen berkelanjutan. Komitmen berdasarkan kerugian yang berhubungan dengan keluarnya karyawan dari organisasi.Ketiga: normative commitment atau komitmen 
normatif.Komitmen normatif berkaitan dengan perasaan wajib untuk tetap berada dalam organisasi karena memang harus begitu (Allen dan Mayer dalam Greenberg \& Baron (2003)

\section{Budaya Organisasi}

Salah satu faktor eksternal yang mempengaruhi kinerja karyawan adalah budaya organisasi.Budaya organisasi merupakan nilai- nilai yang berkembang dalam suatu organisasi, di mana nilai-nilai tersebut digunakan untuk mengarahkan perilaku anggota-anggota organisasi.Robbins (2001) mengatakan budaya organisasi merupakan suatu sistem pengertian bersama yang dipegang oleh anggota suatu organisasi yang membedakan organisasi tersebut dari organisasi lainnya.Hofstede (1986, dalam Koesmono, 2005) menyatakan bahwa budaya merupakan berbagai interaksi dari ciri-ciri kebiasaan yang mempengaruhi kelompok-kelompok orang dalam lingkungannya. Sedangkan Mangkunegara (2005) menyimpulkan pengertian budaya organisasi sebagai seperangkat asumsi atau sistem keyakinan, nilai-nilai dan norma yang dikembangkan dalam organisasi yang dijadikan pedoman tingkah laku bagi anggota-anggotanya untuk mengatasi masalah adaptasi eksternal dan integrasi internal.

Perilaku karyawan tersebut dipengaruhi oleh lingkungan tempat mereka bekerja yang dibentuk melalui budaya organisasi, di mana keberadaan budaya dalam suatu organisasi diharapkan akan meningkatkan kinerja karyawan. Budaya organisasi merupakan pengendali dan arah dalam membentuk sikap dan perilaku para anggota di dalam suatu organisasi. Secara individu maupun kelompok seseorang tidak akan terlepas dari budaya organisasi dan pada umumnya anggota organisasi akan dipengaruhi oleh beraneka ragamnya sumber daya yang ada. Robbins dan Judge (2008), salah satu hasil yang spesifik dari budaya organisasi yang kuat adalah menurunnya tingkat perputaran karyawan. Keharmonisan tujuan yang tercapai antara karyawan dan organisasi melalui budaya akan membangun suatu komitmen organisasional dalam diri karyawan.

Perusahaan dengan budaya yang kuat cenderung akan akan menjadi perusahaan yang sukses. Budaya organisasi yang kuat dapat meningkatkan kompetensi, membangun konsistensi dan komitmen sehingga dengan demikian seluruh anggota organisasi akan termotivasi untuk selalu beradaptasi dengan tuntutan lingkungan yang terus berubah.

Widodo (2010) yang meneliti pada pegawai di Kecamatan Sidorejo Salatiga menemukan bahwa budaya organisasi terhadap kinerja pegawai.Brahmasari dan Suprayetno (2008) yang meneliti di perusahaan yang profit oriented menemukan bahwa budaya organisasi berpengaruh positif terhadap kinerja karyawan.

\section{Kepemimpinan}

Leadership atau kepemimpinan merrupakan salah satu elemen yang bernilai penting dalam sistem manajemen perusahaan. Kepemimpinan adalah proses memengaruhi orang lain kearah tujuan organisasi. Kepemimpinan merupakan kemampuan seseorang untuk memobilisasi, menyelaraskan, memimpin kelompok, menjelaskan gagasan sehingga dapat diterima orang lain. Pemimpin bertanggung jawab untuk menggerakkan setiap usaha dan hambatan untuk menjamin kejelasan visi.Pemimpin harus dapat menciptakan iklim organisasi dimana karyawan meras a bebas tapi penuh tanggung jawab.Riyono dan Zulaifah (2001) mengatakan bahwa kepemimpinan berkaitan dengan kemampuan untuk memotivasi dan 
mempengaruhi bawahan.Seorang pemimpin sukses karena mampu bertindak sebagai pengarah dan pendorong yang kuat serta berorientasi pada tujuan yang ditetapkan.

Hasil dari beberapa penelitian menunjukkan bahwa kepemimpinan sangat diperlukan untuk meningkatkan daya saing perusahaan secara berkelanjutan. Kepemimpinan adalah suatu proses dimana seseorang dapat menjadi pemimpin (leader) melalui aktivitas yang terus menerus sehingga dapat mempengaruhi yang dipimpinnya (followers) dalam rangka untuk mencapai tujuan organisasi atau perusahaan. Gibson dkk.(1996) menyatakan bahwa perilaku pemimpin memiliki dampak atas prestasi bawahannya.Sitio dan Anisykurlillah (2014) yang meneliti tentang kinerja auditor di Kota Semarang menunjukkan bahwa gaya kepemimpinan berpengaruh terhadap kinerja karyawan.

\section{Lingkungan Perusahaan}

Lingkungan kerja memegang peranan penting terhadap baik buruknya kualitas hasil kinerja karyawan.Lingkungan kerja merupakan suatu lingkungan di mana para karyawan tersebut bekerja. Seorang karyawan dalam bekerja akan sangat membutuhkan lingkungan kerja yang kondusif, sehingga mampu meningkatkan kinerjanya. Lingkungan kerja yang kondusif atau sesuai apabila karyawan dapat melaksanakan kegiatan secara optimal, sehat, aman dan nyaman.Supardi (2003:37), menyatakan lingkungan kerja merupakan keaadaan sekitar tempat kerja baik secara fisik maupun non fisik yang dapat memberikan kesan menyenangkan, aman, menentramkan dan kesan betah bekerja dan lain sebagainya. Bila lingkungan kerja nyaman dan komunikasi antar karyawan berjalan lancar, maka bisa dipastikan performa yang dihasilkan pun akan maksimal.

Lingkungan kerja dapat dibagi dalam dua dimensi yaitu lingkungan fisik dan non fisik.Lingkungan kerja fisik adalah segala sesuatu yang bersifat nyata yang berkenaan dengan kondisi tempat atau ruangan dan kelengkapan materi atau peralatan yang diperlukan karyawan untuk bekerja.Lingkungan fisik merupakan segenap faktor fisik yang bersama-sama merupakan suatu suasana fisik yang melingkupi suatu tempat kerja. Lingkungan kerja fisik sebagai kondisi tempat karyawan bekerja yang mencakup: teknik penerangan, suhu udara, suara kebisingan, penggunaan warna dan ruang gerak yang diperlukan (Mangkunegara: 2005).

Lingkungan kerja non fisik merupakan keadaan yang berkaitan dengan hubungan kerja, baik itu hubungan dengan rekan kerja, atasan dan juga bawahan. Lingkungan kerja non fisik ini akan berpengaruh pada kinerja seorang karywan. Untuk menunjang kinerja karyawan yang tinggi sangat diperlukan lingkungan non fisik yang mendukung.

Beberapa hasil penelitian menunjukkan bahwa lingkungan kerja berpengaruh terhadp kinerja karywan.Widodo (2010) memberikan bukti bahwa lingkungan kerja yang efektif dan efisien berpengaruh secara signifikan terhadap kinerja karyawan.Mahardiani dan Pradhanawati (2013) lingkungan kerja fisik berpengaruh positif terhadap kinerja karyawan outsourcing pada Bank BPD Jateng. 


\section{Kerangka Pikir}

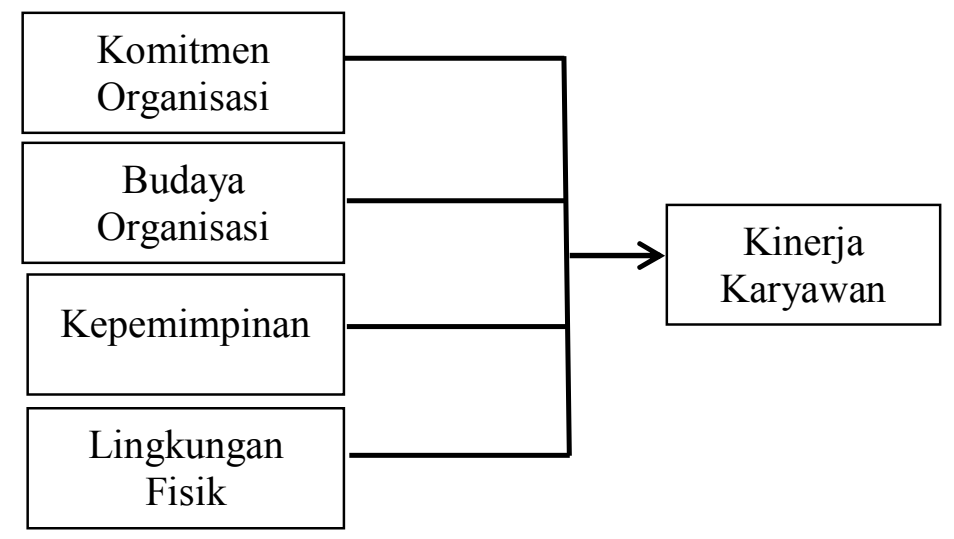

\section{Hipotesis}

Berdasarkan latar belakang dan kajian terori serta beberapa penelitian terdahulu, maka hipotesis dalam penelitian ini dapat dirumuskan sebagai berikut:

$\mathrm{H}_{1} \quad$ : Komitmen organisasi berpengaruh terhadap kinerja karyawan

$\mathrm{H}_{2}$ : Budaya organisasi berpengaruh terhadap kinerja karyawan

$\mathrm{H}_{3} \quad$ : Kepemimpinan berpengaruh terhadap kinerja karyawan

$\mathrm{H}_{4} \quad$ : Lingkungan Kerja Fisik berpengaruh terhadap kinerja karyawan

\section{METODE}

Penelitian ini merupakan penelitian penjelasan (Explanatory research) yang akan membuktikan hubungan kausal antara variabel bebas (independent variable) yaitu variabel komitmen organisasi, budaya organisasi, kepemimpinan, dan lingkungan kerja fisik dan variabel terikat (dependent variable) yaitu kinerja karyawan. Serta penelitian korelasional, yaitu penelitian yang berusaha untuk melihat apakah antara dua variabel atau lebih memiliki hubungan atau tidak, dan seberapa besar hubungan itu serta bagaimana arah hubungan tersebut (Indriyantoro dan Supomo (1999).

Tabel 1.

Variabel Penelitian dan Pengukuran Variabel

\begin{tabular}{|c|c|}
\hline Variabel & Indikator \\
\hline $\begin{array}{l}\text { Kinerja karyawan } \\
\text { (Y) }\end{array}$ & $\begin{array}{l}\text { Kuantitas (Y1), Kualitas (Y2), Efisiensi }(\mathrm{Y} 3) \text {, } \\
\text { Kemampuan (Y4), Ketepatan (Y5), Pengetahuan (Y6), } \\
\text { Kreativitas (Y7). } \\
\text { Sumber: Tsui et al (1997). }\end{array}$ \\
\hline Komitmen & Perasaan menjadi bagian dari organisasi (X11), \\
\hline Organisasi (X1) & $\begin{array}{l}\text { Kebanggaan terhadap organisasi (X12); Kepedulian } \\
\text { terhadap organisasi (X13); Ketertarikan untuk bekerja } \\
\text { pada organisasi (X14); Kepercayaan yang kuat terhadap } \\
\text { nilai-nilai organisasi (X15); Kemauan yang besar untuk } \\
\text { berusaha bagi organisasi (X16). }\end{array}$ \\
\hline
\end{tabular}




\begin{tabular}{ll}
\hline & Sumber: Ganesan dan Weitz (1996) \\
Budaya Organisasi & Keterbukaan (X21), Rasa aman dengan pekerjaan (X22), \\
& Perasaan dihargai (X23), Kerja sama (X24), Kejelasan \\
& organisasi (X25), Dukungan dan perhatian (X26). \\
& Sumber: Hofstede et al. (1993); Kolb et al. (1999) dalam \\
& Mas'ud (2004) \\
& Telling (kemampuan untuk memberitahu anggota apa \\
Kepemimpinan & yang harus mereka kerjakan) (X31), Selling (kemampuan \\
(X3) & menjual/memberikan ide-ide kepadaanggota) (X32), \\
& Participating (kemampuan berpartisipasi dengan anggota) \\
& (X33), dan Delegating (kemampuan mendelegasikan \\
& kepada anggota) (X34). \\
& Sumber: Hersey-Blanchard dalam Robbins (1996) dan \\
& Wirjana dan Supardo (2005) \\
& Suara (X41), keadaan udara (X42), penerangan (X43), \\
kebersihan (X44), tata ruang kerja (X45). \\
Lingkungan Kerja \\
Fisik (X4)
\end{tabular}

Populasi dalam penelitian ini menurut jenisnya merupakan populasi yang terbatas dan menurut sifatnya merupakan populasi yang homogen. Populasi dalam penelitian ini adalah seluruh karyawan yang bekerja pada industri kerajinan kulit, yang berupa tas dan sepatu di Tanggulangin Kabupaten Sidoarjo. Teknik sampling yang digunakan dalam penelitian ini dengan metode atau teknik simple random sampling (teknik sampel sederhana), dimana jumlah sampel sejumlah 65 responden. Jenis data dalam penelitian ini berupa data kualitatif dan sumber datanya berupa data primer.Data yang akan diambil dalam penelitian ini adalah berupa data primer sedangkan metode pengumpulan data dilakukan dengan kuisioner yang diberikan kepada responden secara langsung (Sugiyono, 2005).

Validitas instrumen dalam penelitian ini diuji dengan cara menghitung korelasi spearman dari skor tiap item pertanyaan dengan skor totalnya. Intrumen penelitian dikatan valid jika nilai korelasi $\geq 0,300$. Sedangkan untuk reliabilitas menggunakan Alpha Chronbach.Instrumen penelitian dikatakan reliable jika nilai Alpha Chronbach $>0,60$.

Teknik analisis data digunakan analisis regresi linear berganda. Dalam perhitungan pengolahan data, peneliti mempergunakan alat bantu yang berupa program aplikasi komputer yaitu SPSSversi 18.0.

\section{PEMBAHASAN}

\section{Uji Hipotesis}

Pengujian goodness of fit a statistic model dengan melihat Tabel 3 menunjukkan bahwa secara simultan variabel Komitmen organisasi, Budaya Organisasi, Kepemimpinan dan Lingkungan Fisik Perusahaan berpengaruh terhadap kinerja karyawan. Hal ini ditunjukkan dengan nilai probabilitas $\mathrm{F}$ sebesar 0,000 , dimana nilainya lebih kecil dari 0,05 . Sedangkan untuk uji secara parsial menunjukkan bahwa uji hipotesis 1 untuk variabel Komitmen Organisasi terhadap Kinerja Karyawan nilai probabilitas lebih kecil dari 0,05, yaitu sebesar 0,014 sehingga dapat diambil keputusan Komitmen Organisasi berpengaruh terhadap Kinerja Karyawan. Untuk hipotesis 2, yaitu Budaya Organisasi terhadap Kinerja Karyawan menunjukkan nilai probabilitasnya di bawah 0,05 sehingga dapat 
diambil keputusan Budaya Organisasi berpengaruh terhadap Kinerja Karyawan. Sedangkan untuk hipotesis 3 dan 4, yaitu pengaruh Kepemimpinan terhadap Kinerja Karyawan dan Lingkungan Fisik terhadap Kinerja Karyawan menunjukkan nilai probabilitasnya masing-masing lebih kecil dari 0,05 , yaitu 0,000 dan 0,000 , sehingga dapat diambil keputusan bahwa kepemimpinan dan lingkungan fisik berpengaruh terhadap Kinerja Karyawan. Nilai koefisien determinasi, yang ditunjukkan dengan nilai $\mathrm{R}^{2}$ sebesar0,936. Hal ini menunjukkan bahwa variabel Komitmen Organisasi, Budaya organisasi, Kepemimpinan dan Lingkungan Fisik mampu menjelaskan varian Kinerja karyawan sebesar 93,6 persen, sedang sisanya 6,4 dijelaskan oleh variabel lain diluar model. Kinerja karyawan merupakan unjuk kerja seorang karyawan, semakin tinggi kinerja karyawan akan semakin baik kinerja perusahaan. Karyawan sebagai individu tentunya dalam bekerja akan memperhatikan seberapa besar upah atau gaji dan juga insentif yang akan diterimanya. Sehingga memungkin faktor insentif dan juga faktor yang lain, seperti lingkungan non fisik, tekana kerja juga akan mempengaruhi kinerja seorang karyawan.

Tabel 2.

Ringkasan Hasil Analisis Regresi

\begin{tabular}{|c|c|c|c|r|}
\hline Variabel & $\begin{array}{c}\text { Standardized } \\
\text { Coefficients } \\
\text { Beta }\end{array}$ & $\mathrm{t}$ & Sig. & Keterangan \\
\hline & 0.144 & 2.515 & 0.014 & Signifikan \\
\hline $\mathrm{X} 2$ & 0.322 & 5.023 & 0.000 & Signifikan \\
\hline $\mathrm{X} 3$ & 0.187 & 2.695 & 0.009 & Signifikan \\
\hline $\mathrm{x} 4$ & 0.407 & 6.201 & 0.000 & Signifikan \\
\hline $\mathrm{R}^{2}$ & $: 0.936$ & & \\
$\mathrm{R}_{\text {adjusted }}^{2}$ & $: 0.931$ & & & \\
$\begin{array}{l}\mathrm{F}_{\text {Hitung }} \\
\text { Prob }\end{array}$ & $: 17,0$ \\
0.000
\end{tabular}

Sumber: Hasil pengolahan data

\section{Pembahasan}

\section{Pengaruh Komitmen Organisasi terhadap Kinerja Karyawan}

Berdasarkan pengujian hipotesis menunjukkan bahwa komtmen organisasi berpengaruh terhadap kinerja seorang karyawan.Hasil ini ditopang dengan data lamanya kerja karyawan yang cukup lama bertahan dalam industry kulit dan sepatu di Tanggulangin Sidoarjo.Komitmen organisasi merupakan dimensi perilaku penting seorang karyawan yang dapat digunakan untuk menilai kecenderungan karyawan bertahan dalam suatu anggota organisasi atau perusahaan.Komitmen menunjukkan identifikasi dan keterlibatan seorang karyawan yang relatif kuat terhadap organisasi.Komitmen organisasional yang berpengaruh positif ini menunjukkan bahwa karyawan memiliki Perasaan menjadi bagian dari organisasi, bangga terhadap organisasi, memiliki kepedulian terhadap organisasi, memiliki ketertarikan untuk bekerja pada organisasi.Karyawan memiliki kepercayaan yang 
kuat terhadap nilai-nilai organisasi serta adanya kemauan yang besar seorang karyawan untuk berusaha bagi organisasi.

Karyawan yang memiliki komitmen yang tinggi tinggi, berarti karyawan tersebut akan mempunyai rasa tanggung jawab besar terhadap pekerjaannya. Karyawan dengan komitmen yang tinggi akan mampu menunjukkan kinerja optimal, sehingga akan mampu memberikan kontribusi yang optimal pada organisasi. Komitmen yang tinggi seorang karyawan akan menjadikan dirinya merupakan bagian yang tidak terpisahkan dengan perusahaan, sehingga karyawan akan ikut bertanggung jawab terhadap maju mundurnya perusahaan. Karyawan dengan komitmen yang tinggi tentunya berusaha terus meningkatkan kinerjanya dengan tujuan kemajuan organisasi. Sebaliknya karyawa dengan komitmen yang rendah cenderung akan berdampak pada penurunan kinerjanya. Hasil penelitian ini konsistensi dengan hasil penelitian Jati dan Khusaini (2003), Tobing (2009), Mahennoko (2011), Tolentino (2013), Abrivianto dkk (2014) di mana komitmen organisasi berpengaruh positif terhadap kinerja karyawan.

\section{Pengaruh Budaya Organisasi terhadap Kinerja Karyawan}

Hasil penelitian ini menunjukkan bahwa budaya organisasi berpengaruh positif terhadap kerja karyawan. Karyawan yang sudah memahami keseluruhan nilai-nilai organisasi akan menjadikan nilai-nilai tersebut sebagai suatu kepribadian organisasi. Nilai dan keyakinan tersebut akan diwujudkan menjadi perilaku keseharian mereka dalam bekerja, sehingga akan menjadi kinerja individual. Didukung dengan sumber daya manusia yang ada, sistem dan teknologi, strategi perusahaan sehingga kinerja individu yang baik akan menimbulkan kinerja organisasi yang baik pula.

Budaya organisasi yang tercermin dari keterbukaan manajemen, karyawan yang cenderung dimanusiakan sehingga merasa dihargai membuat karyawan akan merasa aman sehingga kinerjanya akan cenderung tinggi. Budaya organisasi dalam usaha kecil, dimana jumlah tenaga kerja tidak begitu banyak atau bahkan sedikit, sehingga ada kedekatan hubungan antara pemilik dan atau manajemen dengan karyawan cenderung membuat adanya kejelasan organisasi. Dalam organisasi industry kecil yang relatif sederhana, dimana karyawan masih ada hubungan keluraga membuat budaya organisasi yang kuat, sehingga dukungan dan perhatian dari pihak-pihak yang terlibat dalam perusahaan akan semakin kuat. Kondisi demikian cenderung akan mampu meningkatkan kinerja karyawan.

Indikator budaya organisasi yang paling mendominasi adalah perasaan dihargai, di mana hal ini menunjukkan bahwa ketika karyawan merasa dihargai diseuatu perusahaan, maka ketika itu pula keberadaan budaya dirasakan oleh karyawan dan berpengaruh terhadap pada kinerjanya yang semakin baik.

Hasil penelitian ini konsisten dengan temuan Wirawan (2007), Soedjono (2007), Brahmasari dan Suprayetno (2008) dan Widodo (2010) budaya organisasi berpengaruh positif terhadap kinerja karyawan.

\section{Pengaruh Kepemimpinan terhadap Kinerja Karyawan}

Hasil penelitian ini menunjukkan bahwa kepemimpinan berpengaruh positif terhadap kinerja karyawan. Hal ini artinya bahwa kepemimpinan merupakan suatu upaya untuk memengaruhi banyak orang melalui proses komunikasi untuk mencapai tujuan organisasi diharapkan dapat menimbulkan perubahan positif berupa kekuatan dinamis yang dapat mengkoordinasikan organisasi dalam rangka mencapai tujuan perusahaan. Kepemimpinan merupakan suatu proses menggerakkan orang-orang dalam suatu organisasi karena memiliki kekuasaan, 
kewibawaan dan kemampuan, agar bekerja dalam suasana moralitas yang tinggi dengan penuh semangat dapat menyelesaikan pekerjaannya masing-masing sesuai hasil yang diharapkan. Hal ini menunjukkan bahwa kepemimpinan pada industri kecil cenderung akan mampu menggerakkan karyawan yang ada, sesuai dengan apa yang diharapkan oleh perusahaan (pemilik). Pemilik industri kecil kulit dan tas di Tangggulangin rata-rata akan berperan sebagai manajemennya yang mereka memiliki knowledge yang baik terhadap bagaimana bahan dan produk tersebut di buat. Sehingga kemampuannya dalam hal telling, selling, participating dan delegating cenderung baik. Kemampuan yang dimiliki manajemen serta ditambah dengan Karyawan yang sebagian masih ada hubungan keluarga kondisi demikian tentunya akan cenderung akan berdampak positif pada kinerja karyawan.

Hasil penelitian ini konsisten dengan temuan penelitian Widyatmini dan Hakim (2008), Apriani (2009), dan Sitio dan Anisykurlillah (2014) dimana kepemimpinan berpengaruh positif terhadap kinerja karyawan.

\section{Pengaruh Lingkungan Fisik terhadap Kinerja Karyawan}

Lingkungan fisik merupakan sesuatu yang berada di lingkungan kerj yang dapat mempengaruhi baik secara langsung maupun tidak langsung seseorang atau sekelompok orang didalam melaksanakan aktivitasnya.Hasil penelitian menunjukkan bahwa lingkungan fisik berpengaruh terhadap kinerja seorang karyawan. Artinya lingkungan fisik yang semakin baik akan mampu meningkatkan kinerja karyawan. Lingkungan kerja yang baik artinya lingkungan kerja tersebut sesuai dengan tuntutan dan kebutuhan karyawan untuk menyelesaikan pekerjaannya. Dalam industry kecil kulit dan tas tentunya lingkungan yang sesuai dengan apa yang dibutuhkan karyawan salam menyelsaikan pembuatan tas, sepatu dan kerajinan kulit yang lainnya.

Berdasarkan penelitian lingkungan fisik berupa suara cukup mendukung karyawan dalam menyelesaikan pekerjaan. Rata-rata bengkel kerja karyawan ada lantunan suatu radio atau tape yang membuat mereka tidak cepat lelah. Sedangkan dari sisi keadaan udara relatif tidak begitu panas, karena rata-rata tersedia kipas angin selain itu para karyawan berasal dari daerah disekitaran Tanggulangin sendiri sehingga suhu dan keadaan udara tidak berbeda dengan di tempat tinggalnya.Penerangan tempat kerja cukup baik, sedangkan kebersihan relative baik karena adanya pemisahan ruang atau bengkel kerja dari masing-masing bagian, misalnya untuk pengepakan, bahan dan pemotongan bahan.

Temuan penelitian ini sesuai dengan teori, dimana lingkungan fisik akan berpengaruh terhadap kinerja karyawan. Hasil penelitian ini konsisten dengan temuan Widodo (2010), Mahardiani dan Pradhanawati (2013) dimana lingkungan kerja fisik berpengaruh positif terhadap kinerja karyawan.

\section{KESIMPULAN}

Berdasarkan hasil analisis dan pembahasan yang telah dilakukan dapat ditarik simpulan bahwa komitmen organisasi, budaya organisasi, kepemimpinan dan lingkungan kerja fisik berpengaruh terhadap kinerja karyawan pada industry kecil kulit dan tas di Lingkungan Industri Tanggulangin Sidoarjo. Komitmen organisasi yang tinggi akan berpengaruh positif terhadap kinerja karyawan. Sedangkamn Budaya organisasi yang kuat, yang mampu tertanam pada seluruh 
anggota organisasi, dalam hal ini karyawan mampu meningkatkan kinerja karyawan. Kepemimpinan yang mampu mendelegasikan, berpartisipasi atau mampu membaur dengan karyawan serta knowledge tentang produk cenderung akan mampu mengkomunikan dan mempengaruhi karyawan sesuai dengan akan yang diinginkan perusahaan. Lingkungan fisik pada perusahaan sangat mendukung kinerja karyawan.

\section{Saran}

Penelitian ini terbatas pada tenaga kerja atau pengrajin kulit tas dan sepatu di Tanggulangin, dengan variabel yang masih terbatas pada komitmen dan budaya organisasi, kepemimpinan serta lingkungan kerja fisik. Untuk penelitian selanjutnya dapat dilakukan pada industri atau perusahaan dengan karakteristik pekerjaan yang berbeda, selain itu perlu dilakukan penelitian dengan menambah variabel lain baik yang sifatnya internal dari karyawan, seperti tekan kerja dan sistem pengupahan yang digunakan.

\section{DAFTAR PUSTAKA}

Abrivianto, P Okto Abrivianto. Swasto, Bambang. Utami, Hamidah Nayati. 2014. Pengaruh Motivasi Kerja dan Komitmen Organisasional Terhadap Kinerja Karyawan (Studi pada karyawan bagian HRD PT. Arthawena Sakti Gemilang Malang).Jurnal Administrasi Bisnis (JAB). Vol. 7 (2)

Agustian, Ary Ginanjar. 2006. Rahasia SuksesMembangun Kecerdasan Emosi Dan Spiritual; Jakarta, Penerbit Arga.

Anik, Sri dan Ariffudin. 2003. Analisis PengaruhKomitmen Organisasi dan Keterlibatan Kerja terhadap Hubungan antara Etika Kerja Islam dengan Sikap Perubahan Organisasi.JAAI. Vol. 7 (2)

Apriani, Fajar. 2009. Pengaruh Kompetensi, Motivasi, dan Kepemimpinan terhadap Efektivitas Kerja. Bisnis \& Birokrasi, Jurnal Ilmu Administrasi dan Organisasi. Vol. 16 (1)

Bernardin, H. J. 2007. Human resource management: an experiential approach (4rd ed.). USA: McGraw-Hill.

Brahmasari, Ida Ayu dan Suprayetno, Agus. 2008. Pengaruh Motivasi Kerja, Kepemimpinan dan Budaya Organisasi Terhadap Kepuasan Kerja Karyawan serta Dampaknya pada Kinerja Perusahaan (Studi kasus pada PT. Pei Hai International Wiratama Indonesia). Jurnal Manajemen dan Kewirausahaan. Vol 10 (2)

Ganesan, Shankar dan Barton A. Weitz, 1996, The Impact of Staffing Policies on Retail Buyer Job Attitudes and Behaviors, Journal of Retalling, 72(1).

Gibson, James., John M. Ivancevic, dan James H. Donnelly. 1996. Organisasi: Perilaku, Struktur, dan Proses. Terjemahan.Jilid 1. Jakarta: Erlangga 
Greenberg, J. \& Baron, R.A. 2003.Behaviorin Organizations Understanding and Managing the Human Side of Work.New Jersey: Prentice-Hall International

Griffin, R.W. 2004. Management, $7^{\text {th }}$ edi-tion.Massachusetts: Houghton MifflinCompany

Hofstede, G. J. 1993. Cultural Constraints in Management Theories. In J. T. Wren (Ed.), The leader's Companion. New York: Free Press.

Jati, S. Pantja dan Khusaini, M. 2003. Kajian Terhadap Kepuasan Kompensasi, Komitmen Organisasi, Dan Prestasi Kerja. Jurnal Manajemen \& Kewirausahaan Vol. 5 (1)

Khan, Muhammad Riaz et al. 2010.The Impactof Organizational Commitment on Employee Job Performance.European Journal of Social Sciences. 15(3)

Koesmono, H.T. 2005.Pengaruh Budaya Organisasi Terhadap Motivasi danKepuasan Kerja Serta Kinerja Karyawan Pada Sub Sektor Industri Pengolahan Kayu Skala Menengah di Jawa Timur.Jurnal Manajemen dan Kewirausahaa. Vol 7 (2)

Lok, P and Crawford, D. 2004. The Effect of Organizational Culture and LeadershipStyle on Job Satisfaction and Organizational Commitment - A Cross National Comparison.The Journal of Management Development, Vol. 23 (4)

Luthans, F. (1995) Organizational Behavior. New York: McGraw-Hill

Mahardiani, Yoanisa dan Pradhanawati, Ari.2013. Pengaruh Stres Kerja dan Lingkungan Fisik Terhadap Kinerja Karyawan Outsourcing Pada PT. Bank Jateng Cabang Koordinator dan Cabang Pembantu Wilayah Kota Semarang.Jurnal Administrasi Bisnis Vol. 2 (1)

Mangkunegara, A.,A.,P., 2005. Perilaku dan Budaya Organisasi, Bandung: PT.Refika Aditama.

Martoyo. 2007. Manajemen Sumber DayaManusia. Edisi Kelima. Penerbit BPFE,Yogyakarta

Mas'ud, Fuad. 2004. Survai Diagnosis Organisasional: Konsep dan Aplikasi, Semarang: Badan Penerbit Undip.

Mathis, R,L, dan Jackson. 2002. Manajemen Sumber Daya Manusia, Jilid 1 dan 2, Alih bahasa : Bayu Brawira, Salemba Empat, Jakarta

Morrison. 1997. How Franchise Job Satisfaction and Personality Affects Performance, Organizational Commitment, Franchisor Relation and Intention to Remain, Journal of Small Business Management 
76 MODERNISASI, Volume 11, Nomor 1, Februari 2015

Moekijat.1995. Manajemen Personalia dan Sumber Daya Manusia.Bandung: Mandar Maju.

Northouse, P.G. 2003. Leadership: Theory and Practice, Third Edition. New Delhi: Response Book

Nunnally, J. C. 1978. Psychometric Theory. New York: McGraw Hill Book Co.

Rachmadita, Renanda Nia, Kurniasih, Dewi. Dan Sandora, Rina. 2011. Analisis Pengaruh Budaya Organisasi terhadap Loyalitas Karyawandan Keterkaitannya dengan Kesehatan.Jurnal Teknik dan Manajemen Industri. Volume $6(2)$

Robbins, S. \& Judge, T. 2007.OrganizationalBehavior, 12th edition. New York: Prentice Hall

Robbins, Stephen, P., 2001. Organizational Behavior, Ninth Edition, New Jersey: Prentice Hall International, Inc.

Sekaran, Uma (2004), Research Method of Business,New York: John Wiley \& Son, Inc.

Sitio, Ristia dan Anisykurlillah, Indah. 2014. Pengaruh Pemahaman Good Corporate Governance, Gaya Kepemimpinan, Budaya organisasi dan Struktur Audit Terhadap Kinerja Auditor (Studi Empiris Pada Kantor Akuntan Publik Di Kota Semarang. Accounting Analysis Journal 3 (3)

Soedjono.2005. Pengaruh Budaya Organisasi Terhadap Kinerja Organisasidan Kepuasan Kerja Karyawan pada Terminal PenumpangUmum di Surabaya.Jurnal Manajemen \& Kewirausahaan Vol. 7 (1)

Sugiyono.2004 .Metode Penelitian Bisnia .Bandung : CV .Alfabeta.

Supardi. 2003. Kinerja Karyawan. Ghalia Jakarta

Timpe, A. D. 1993. Kinerja (performance).Jakarta: Gramedia.

Tobing, KL dan Diana Sulianti.2009. Pengaruh Komitmen Organisasional dan Kepuasan Kerja Terhadap Kinerja Karyawan PT. Perkebunan Nusantara III di Sumatera Utara.Jurnal Manajemen dan Kewirausahaan. Vol 11 (1)

Tsui, Anne S. et al., 1997, Alternative Approachesto the Employee-Organization Relationship: Does Investment in Employees Pay Off?, Academy of Management Journal, 40 (5)

Umam, Khaerul, 2010. Perilaku Organisasi. Bandung : CV. Pustaka Setia

Widodo, Tri. 2010. Pengaruh Lingkungan Kerja, Budaya Organisasi, Kepemimpinan Terhadap Kinerja (Studi pada Pegawai Kecamatan Sidorejo Kota Salatiga Among Makarti. Vol.3 (5) 
Widyatmini dan Hakim, Luqman. 2008. Hubungan Kepemimpinan, Kompensasi dan Kompetensi Terhadap Kinerja Pegawai Dinas Kesehatan Kota Depok. Jurnal Ekonomi Bisnis Vol. 13 (2)

Wirawan. 2007. Budaya dan Iklim Organisasi Teori: Aplikasi dan Penelitian. Jakarta :Penerbit Salemba

Wirjana Bernardine R., 2005. Supardo Susilo, Kepemimpinan, Cetakan Pertama, Penerbit Andi, Yogyakarta

Yukl, Gary. 2005. Kepemimpinan Dalam Organisasi ; Jakarta, Penerbit PT. Indeks.

Yuninigsih.2002. Membangun Komitmen dan Menciptakan Kinerja Sumber Daya Manusia Untuk Memperoleh Keberhasilan Perusahaan.Fokus Ekonomi Vol.1 (1) 